\title{
Distribution of phosphatase activity in marsh sediments along an estuarine salinity gradient
}

\author{
Xiaoqing Huang ${ }^{1,2, *}$, James T. Morris ${ }^{1}$ \\ ${ }^{1}$ Department of Biological Sciences, University of South Carolina, 700 Sumter Street, Columbia, South Carolina 29208, USA \\ ${ }^{2}$ Present address: Earth Sciences and Resources Institute, University of South Carolina, 901 Sumter Street, Columbia, \\ South Carolina 29208, USA
}

\begin{abstract}
Acid phosphatase activity (APA) was measured in intertidal marsh sediments located along the Cooper River estuary, South Carolina, at North Inlet, SC, and in a marsh on the Rowley River, MA. We found that APA increased from $4.3 \pm 2.3$ to $29.3 \pm 18.8 \mu \mathrm{mol}$ p-nitrophenol released $\mathrm{g}^{-1} \mathrm{~h}^{-1}$ with decreasing sediment salinity from $22 \mathrm{~g} \mathrm{l}^{-1}$ to $0.1 \mathrm{~g} \mathrm{l}^{-1}$. A study of APA kinetics revealed that the maximum specific activity $\left(V_{\max }\right)$ followed the same trend as in situ phosphatase activity. Sediment salinity $\left(\mathrm{p}<0.05 ; \mathrm{R}^{2}=0.43\right)$ and $\mathrm{pH}\left(\mathrm{p}<0.01 ; \mathrm{R}^{2}=0.56\right)$ were negatively correlated with APA, while soil organic matter (SOM) content $\left(p<0.01 ; R^{2}=0.57\right)$, clay content $\left(p<0.05 ; R^{2}=0.37\right)$ and sediment organic $\mathrm{P}(\mathrm{SOP})\left(\mathrm{p}<0.01 ; \mathrm{R}^{2}=0.50\right)$ were positively correlated. Collectively, these variables accounted for $78 \%$ of the variation in APA $(\mathrm{p}<0.05)$. APA was not significantly correlated with sulfide, $\mathrm{NH}_{4}{ }^{+}$, soluble reactive phosphorus (SRP), sediment total $\mathrm{P}$, the N:P ratio, aboveground biomass, or macro-organic matter content. In salt marsh plots at North Inlet that were experimentally fertilized with $\mathrm{N}$ and $\mathrm{P}$, we found that fertilization with only $\mathrm{P}$ had no effect on APA, while $\mathrm{N}$-only or $\mathrm{N}+\mathrm{P}$ fertilization significantly increased APA to $6.4 \mu \mathrm{mol} p$-nitrophenol released $\mathrm{g}^{-1} \mathrm{~h}^{-1}$ from $1.5 \mu \mathrm{mol}$ $\mathrm{p}$-nitrophenol released $\mathrm{g}^{-1} \mathrm{~h}^{-1}$ in control plots. However, even in the fertilized salt marsh plots, APA was still significantly lower than in freshwater, oligohaline and mesohaline marshes.
\end{abstract}

KEY WORDS: Acid phosphatase activity · Marsh sediment $\cdot$ Salinity gradient $\cdot$ Estuary

\section{INTRODUCTION}

Phosphatase enzymes are fundamental to phosphorus cycling in many aquatic and terrestrial ecosystems (McGill \& Cole 1981, Wetzel 1991), because organic forms of $\mathrm{P}$ must be hydrolyzed by phosphatases in order to liberate the inorganic phosphorus moiety before it can be utilized by plants and microbes. Orthophosphate and a few other inorganic phosphorus species (Sundareshwar et al. 2003) are effectively the sole direct sources of phosphorus available to plants and microbes. In aquatic ecosystems, phosphorus is frequently a limiting factor for primary production. This has been the rationale for numerous investigations of phosphorus biogeochemistry. Huang \& Morris (2003) demonstrated that in the sediments of tidal freshwater marshes, phosphatase activity increased as plant demand for P increased along a successional gradient and as soluble reactive phosphorus (SRP) in porewater was depleted. They speculated that an autocatalytic positive feedback between $\mathrm{P}$ assimilation and synthesis of phosphatase enzymes helps to drive marsh succession from an early, open-water stage towards a late intertidal emergent macrophyte stage.

Numerous studies have demonstrated that, under a condition of phosphorus deficiency, algae, bacteria and plant roots can be induced to secrete phosphatase enzymes (Bieleski \& Johnson 1972, Patni et al. 1977, Tadano et al. 1993). However, phosphatase activity cannot influence $\mathrm{P}$ uptake by plants when the concentration of organic phosphorus, its substrate in the rhizosphere, is limiting (Bieleski 1973). Wetzel (1991) hypothesized that no advantage can be gained by releasing extracellular enzymes from cells into the immediate micro- 
environment when the distance between the cell and substrate is more than $500 \mu \mathrm{m}$. In addition, phosphatase enzymes in the sediment are subject to degradation by proteases or other enzymes, making it energetically expensive for plants or microbes to secrete phosphatase. Selective pressures may then favor plants and microbes that turn to other mechanisms for regenerating inorganic phosphorus.

To further our understanding about the regulation of these biogeochemical patterns in intertidal freshwater and salt marshes, we examined the acid phosphatase activity (APA) of sediments collected from several estuaries, including the Cooper River and North Inlet in South Carolina, and Plum Island Sound in Massachusetts, in relation to important abiotic and biotic properties of the sediments such as organic matter content, $\mathrm{pH}$, nutrient availability and salinity. We were particularly interested in whether there was a trend in APA along the estuarine salinity gradient in the Cooper River, SC, as it is generally accepted that phosphorus limitation of primary producers tends to occur in freshwater ecosystems, while nitrogen limitation occurs in marine ecosystems.

\section{MATERIALS AND METHODS}

Site description. Cooper River, South Carolina: The Cooper River (CR), which flows into Charleston Harbor, has a stable salinity distribution that was formed after a rediversion project in 1985 that reduced the freshwater discharge into the river from 418 to $122 \mathrm{~m}^{3}$ $\mathrm{s}^{-1}$ (Kjerfve \& Magill 1990). Eight sites were selected along the salinity gradient on the $\mathrm{CR}$, including 6 from different types of tidal freshwater marshes, 1 from a tidal oligohaline marsh and 1 from a tidal mesohaline marsh. The mean porewater salinity at the oligohaline site (referred to here as Dense Emergent Site 3) in surface sediment $(0$ to $10 \mathrm{~cm}$ ) and at a distance of $10 \mathrm{~m}$ from the river bank was $1.1 \mathrm{~g} \mathrm{l}^{-1}$ (Table 1). This site was dominated by Spartina cynosuroides and broad-leaved species. Porewater $($ depth $=0$ to $10 \mathrm{~cm}$ ) salinity at the mesohaline site (Dense Emergent Site 4) was $4.7 \mathrm{~g} \mathrm{l}^{-1}$. The interior of this site was dominated by Juncus roemerianus with fringes of $S$. alterniflora and S. cynosuroides along the river's edge. Our sample site was located about $10 \mathrm{~m}$ from the river bank inside a stand of $J$. roemerianus.

We also sampled 4 tidal freshwater and 2 subtidal freshwater sites representing 5 different stages of succession (Huang \& Morris 2003). They included shallow subtidal sediments with and without submerged aquatic vegetation (SAV), mixed submerged emergent vegetation, and intertidal sediments in communities of developing and closed canopy emergent vegetation. Porewater salinity in the surface $10 \mathrm{~cm}$ of sediment averaged $0.08 \mathrm{~g} \mathrm{l}^{-1}$. All of these sites were former rice field impoundments and are now tidal freshwater wetlands. A site early in succession was characterized by a dense SAV community consisting of Egeria, Cabomba and Hydrilla spp. The next stage included both SAV and emergent vegetation, while the last stage was charac-

Table 1. Habitat characteristics of 15 study sites, located in 3 estuaries. Grand geometric mean concentrations $\left(\mu m o l \mathrm{l}^{-1}\right)$ are shown for $\mathrm{NH}_{4}{ }^{+}$, sulfide, soluble reactive phosphorus (SRP), and for ratios of $\mathrm{NH}_{4}{ }^{+}: \mathrm{SRP}$ in porewater $(10 \mathrm{~cm} \mathrm{depth}$; $\mathrm{n}=64)$. Also shown are arithmetic means $( \pm \mathrm{SD})$ of aboveground biomass, sediment organic matter $(\mathrm{SOM})(\mathrm{n}=6)$, clay content $(\%)(\mathrm{n}=3)$ in the depth range 0 to $10 \mathrm{~cm}$, and sediment $\mathrm{pH}(\mathrm{n}=6)$. SAV: submerged aquatic vegetation

\begin{tabular}{|c|c|c|c|c|c|c|c|c|c|c|c|}
\hline Estuary & Site & $\begin{array}{l}\text { Marsh } \\
\text { type }\end{array}$ & $\begin{array}{c}\text { Salinity } \\
\left(\mathrm{g} \mathrm{l}^{-1}\right)\end{array}$ & $\begin{array}{c}\text { Biomass } \\
\left(\mathrm{g} \mathrm{m}^{-2}\right)\end{array}$ & $\begin{array}{c}\text { SOM } \\
(\%)\end{array}$ & $\begin{array}{l}\text { Clay } \\
(\%)\end{array}$ & $\mathrm{pH}$ & $\mathrm{S}^{2-}$ & $\mathrm{NH}_{4}^{+}$ & SRP & $\mathrm{N}: \mathrm{P}$ \\
\hline \multirow[t]{8}{*}{$\begin{array}{l}\text { Cooper } \\
\text { River }\end{array}$} & $\begin{array}{l}\text { Subtidal non } \\
\text { vegetated }\end{array}$ & Open water & 0.08 & $10(5)$ & $13(2.4)$ & 53 & 6.2 & 0.8 & 311.0 & 14.4 & 22.3 \\
\hline & SAV & Open water & 0.07 & $327(32)$ & $17(1.4)$ & 58 & 5.4 & 0.7 & 698.8 & 26.8 & 26.7 \\
\hline & SAV + emergent & Tidal freshwater & 0.1 & $633(97)$ & $21(1.2)$ & 32 & 5.6 & 1.1 & 317.4 & 19.7 & 16.6 \\
\hline & Sparse emergent & Tidal freshwater & 0.08 & $350(213)$ & $21(0.5)$ & 50 & 5.7 & 0.7 & 227.2 & 22.3 & 10.4 \\
\hline & Dense emergent 1 & Tidal freshwater & 0.07 & $793(25)$ & $27(0.9)$ & 46 & 5.4 & 2.6 & 17.6 & 3.3 & 6.0 \\
\hline & Dense emergent 2 & Tidal freshwater & 0.07 & 949 (143) & $25(4.4)$ & 49 & 5.3 & 0.9 & 20.8 & 2.0 & 11.7 \\
\hline & Dense emergent 3 & Tidal oligohaline & 1.1 & $1402(243)$ & $27(1.4)$ & 25 & 6.6 & 9.2 & 19.9 & 8.3 & 3.38 \\
\hline & Dense emergent 4 & Tidal mesohaline & 4.7 & $1675(278)$ & $28(0.1)$ & 15 & 7.1 & 28.0 & 37.8 & 8.5 & 5.9 \\
\hline North & Control & Tidal polyhaline & 22 & $350(21)$ & $6(1.6)$ & & 7.3 & 1.4 & 18.8 & 0.8 & 31.2 \\
\hline \multirow{4}{*}{ Inlet } & P-fertilized & Tidal polyhaline & 22 & 310 (29) & $6(1.2)$ & & 7.1 & 1.5 & 29.2 & 15.5 & 1.8 \\
\hline & N-fertilized & Tidal polyhaline & 22 & $750(86)$ & $8(2.2)$ & 5 & 7.2 & 0.7 & 52.6 & 0.7 & 55.2 \\
\hline & $\mathrm{N}+\mathrm{P}$-fertilized & Tidal polyhaline & 22 & $1105(206)$ & $9(1.2)$ & & 7.3 & 0.9 & 110.4 & 17.2 & 4.8 \\
\hline & $\mathrm{N}+\mathrm{P}-15 \mathrm{yr}$ & Tidal polyhaline & 22 & $1751(137)$ & $17(0.2)$ & & 7.3 & 7.9 & 79.6 & 30.1 & 3.97 \\
\hline Plum & Control & Tidal polyhaline & 24 & $590(135)$ & $14(0.4)$ & - & - & 76.4 & 26.4 & 9.6 & 2.5 \\
\hline Island & $\mathrm{N}+\mathrm{P}$-fertilized & Tidal polyhaline & 24 & 1115 (259) & $17(0.4)$ & - & - & 6.5 & 568.5 & 319.1 & 1.8 \\
\hline
\end{tabular}


terized by dense emergent vegetation, including Zizania aquatica, Spartina cynosuroides and others.

North Inlet, South Carolina: We sampled a polyhaline salt marsh located at North Inlet, South Carolina along a tidal creek where porewater salinity at $10 \mathrm{~cm}$ depth averaged $22 \mathrm{~g} \mathrm{l}^{-1}$. The plant community was dominated by a monoculture of Spartina alterniflora. In 1996, triplicate $1 \mathrm{~m}^{2}$ plots were randomly selected for treatment as either control, N-only fertilization, P-only fertilization, or N + P fertilization. Commercial ammonium nitrate and phosphate were applied every other month at $4.34 \mathrm{~mol} \mathrm{~N} \mathrm{~m}^{-2}$ for the $\mathrm{N}$ treatment and $2.16 \mathrm{~mol} \mathrm{P} \mathrm{m}^{-2}$ for the $\mathrm{P}$ treatment. The fertilizer was applied by burying it under small sediment cores $5 \mathrm{~cm}$ below the sediment. The plots had been fertilized for $5 \mathrm{yr}$ before sediment samples were collected in July 2001. At the same location, we also sampled plots ( $\mathrm{n}=$ 3 ) that had been fertilized for $15 \mathrm{yr}$ with a combination of $\mathrm{N}$ and $\mathrm{P}$ at the same rates as the $\mathrm{N}$ only and $\mathrm{P}$ only treatments.

Rowley River, Massachusetts: We sampled a salt marsh site on the Rowley River, Massachusetts in the Plum Island Estuary. This site had a porewater salinity of $24 \mathrm{gl}^{-1}$ (at $10 \mathrm{~cm}$ depth) and a plant community dominated by Spartina alterniflora, similar to that in the salt marsh at North Inlet, South Carolina. An N and P factorial fertilization experiment was also established here starting in the summer of 1999 like that at North Inlet. Cores were collected here for phosphatase activity in July 2001 after the plots had been fertilized for $2 \mathrm{yr}$.

Phosphatase activity. APA was measured using the modified method of Tabatabai (1982) at pH 6.5 in modified universal buffer (MUB), at a pH that effectively selects acid phosphatase over other forms. Fresh sediment ( $1 \mathrm{~g}$ dry weight equivalent) was placed in a $15 \mathrm{ml}$ plastic tube, and was brought to $8 \mathrm{ml}$ volume with MUB, followed by $0.2 \mathrm{ml}$ toluene and $1 \mathrm{ml}$ of substrate solution (p-nitrophenyl phosphate in MUB solution). Ingredients were mixed, the tubes capped and placed in an incubator at $37^{\circ} \mathrm{C}$ for $1 \mathrm{~h}$, and then $1 \mathrm{ml}$ of $0.5 \mathrm{M}$ $\mathrm{CaCl}_{2}$ and $4 \mathrm{ml}$ of $0.5 \mathrm{M} \mathrm{NaOH}$ solution were added to each tube. The tubes were shaken and the resulting sediment suspension filtered (No. 42 Whatman filter paper). The filtrate was analyzed spectrophotometrically at a wavelength of $400 \mathrm{~nm}$. Controls were processed in the same way, except that substrates were added after an incubation period and then filtered immediately. Controls were used to correct for the natural hydrolysis of the substrate reagent. This is especially important when high substrate concentrations are used, as failure to correct for natural hydrolysis will lead to inflated estimates of phosphatase activity. Measurements of phosphatase kinetics were performed similarly by varying the initial substrate concentration, ranging nominally from 0.5 to $25.0 \mathrm{mM}$.
Porewater chemistry. Porewater was collected monthly in triplicate at 5 depths from each site using a diffusion sampler from August 1998 to October 2000. The sampling device consisted of a PVC pipe that held glass vials (30 ml volume) at depths of $10,25,50,75$ and $100 \mathrm{~cm}$ from the sediment surface. The vials were filled with distilled water and screened with a $45 \mu \mathrm{m}$ mesh Nitex membrane held in place by a serum cap. These samplers were inserted into the sediment and allowed to equilibrate with the porewater for $1 \mathrm{mo}$. Retrieved samples were kept on ice and analyzed the following day.

Porewater soluble reactive phosphorus (SRP) was analyzed spectrophotometrically by the ammonium molybdate-ascorbic acid method (Strickland \& Parsons 1972). For $\mathrm{NH}_{4}{ }^{+}$, a portion of each water sample was preserved with $10 \%$ phenol in the field and then analyzed the following day by the dichloroisocyanuratenitroprusside method (Strickland \& Parsons 1972). A modification of Cline's (1969) method using N, N-dimethyl-p-phenylenediamine sulfate (Otte \& Morris 1994) was used to measure sulfide. $\mathrm{Cl}^{-}$was measured by coulometric titration (Haakebuchler chloridometer). Salinity was defined by the Knudsen equation in terms of Cl (Strickland \& Parsons 1972):

$$
\mathrm{S}\left(\mathrm{g} \mathrm{l}^{-1}\right)=0.030+1.8050 \times \mathrm{Cl}^{-}\left(\mathrm{g} \mathrm{l}^{-1}\right)
$$

From a sediment slurry prepared with deionized water at a 1:2 sediment:water ratio, $\mathrm{pH}$ was measured using an Orion model 399A pH meter with a calomel electrode inserted in the suspension.

Clay content. Organic matter was removed from oven-dry ground sediment by peroxide oxidation. After adjusting the $\mathrm{pH}$ to 7.3 with $1 \mathrm{M} \mathrm{NaOH}$, the clay fraction $(<2 \mathrm{~mm})$ was separated by gravity sedimentation and expressed as a percentage of total dry sediment weight (Gee \& Bauder 1982).

Organic matter and macro-organic matter content. Sediment cores $(0$ to $10 \mathrm{~cm}$ ) were broken and pressed through a $2 \mathrm{~mm}$ sieve. The plant materials retained on the sieve were defined as the macro-organic matter fraction (live and dead roots, or plant residuals). Macro-organic matter content in the depth range 0 to $10 \mathrm{~cm}$ was estimated from at least 9 cores for each treatment, and it was adjusted by subtracting the ash following combustion because of the difficulty of completely separating the roots from the sediment. Three replicates of sediment samples were dried to constant weight in an oven at $105^{\circ} \mathrm{C}$ before they were ashed at $550^{\circ} \mathrm{C}$ for $6 \mathrm{~h}$. Organic matter content was estimated on the basis of ignition loss.

Total, extractable and organic phosphorus. Extractable phosphorus was determined using the method of Olsen \& Sommers (1982) by treating sediment samples with a $0.025 \mathrm{M} \mathrm{NH}_{4} \mathrm{~F}-0.03 \mathrm{M} \mathrm{HCl}$ solution using a wet 
soil:solution ratio of $2 \mathrm{~g}: 20 \mathrm{ml}$ in $50 \mathrm{ml}$ plastic centrifuge tubes. The tubes were put on a shaker table overnight and then centrifuged at $1000 \times g$ for $10 \mathrm{~min}$. The supernatants were then filtered using No. 42 Whatman filter paper. The supernatants were analyzed spectrophotometrically for extractable phosphorus as described above.

Total sediment phosphorus, based on a modification of the method of Olsen \& Sommer (1982), was measured by digesting $0.2 \mathrm{~g}$ of dry, ground sediment with $5 \mathrm{ml} \mathrm{HF}(40 \%)$ and $5 \mathrm{ml} \mathrm{HClO}_{4}(60 \%)$ solution on a hot plate. Further additions of HF were made until the sediment was whitened and the solution was clear, and the crucible was kept hot until the sediment was nearly dry. After cooling, $1 \mathrm{ml}$ of $0.5 \mathrm{M} \mathrm{H}_{2} \mathrm{SO}_{4}$ were added to the digested sediment, stirred and then washed into a $50 \mathrm{ml}$ volumetric flask. The total volume was then brought to $50 \mathrm{ml}$ with distilled water. An aliquot of the supernatant (depending on its $\mathrm{P}$ content) was pipetted into a vial and its $\mathrm{pH}$ was adjusted to neutrality by $0.5 \mathrm{M} \mathrm{NaOH}$, the total volume brought to $25 \mathrm{ml}$ with distilled water, and the orthophosphorus in solution analyzed spectrophotometrically as described above. Organic phosphorus was calculated as the difference between total sediment phosphorus and extractable phosphorus.

Biomass measurements. Peak aboveground standing biomass was measured by removing the standing aboveground vegetation from a $2500 \mathrm{~cm}^{2}$ quadrant that was randomly tossed. Six replicate samples were collected from each site during August and September. Plant samples were dried to constant weight in a $65^{\circ} \mathrm{C}$ oven.

Data analysis. We fitted the phosphatase activity from the kinetic experiments to the Michaelis-Menten equation:

$$
V=\frac{V_{\max } \times[S]}{K_{\mathrm{m}}+[S]}
$$

where $V$ is phosphatase activity, $V_{\max }$ is the maximum activity, $K_{\mathrm{m}}$ is the Michaelis constant and [S] is the concentration of substrate (p-nitrophenyl phosphate). Estimates of the kinetic parameters $V_{\max }$ and $K_{\mathrm{m}}$ were obtained by nonlinear parameter estimation (Proc Model; PC SAS, version 8.02). N:P molar ratios were calculated on individual samples and then averaged by treatment. Grand-geometric means of $\mathrm{Cl}^{-}, \mathrm{S}^{2-}, \mathrm{SRP}$, $\mathrm{NH}_{4}{ }^{+}$and the N:P ratio were calculated from the lognormalized monthly data. The statistical significance of differences in nutrient concentrations, phosphatase activity and standing biomass were evaluated by using Tukey's Studentized range test or Scheffé's test. Correlations between marsh properties and phosphatase activity were determined by linear regression (Proc Reg; PC SAS, version 8.02).

\section{RESULTS}

\section{Habitat characteristics}

Porewater salinity ranged from 0.07 to $4.7 \mathrm{~g} \mathrm{l}^{-1}$ among the 8 marsh habitats along the Cooper River, South Carolina (Table 1). The habitats were broadly classified into 3 categories, i.e. freshwater, oligohaline and mesohaline, according to their salinity. The 6 habitats classified as tidal freshwater marshes represent a gradient of successional stages ranging from subtidal to mixed submerged emergent vegetation, leading to intertidal emergent vegetation (Huang \& Morris 2003). Standing biomass and sediment organic matter (SOM) content tended to increase along the successional gradient and from freshwater to mesohaline sites. Biomass and SOM increased from $10 \mathrm{~g} \mathrm{~m}^{-2}$ and $13 \%$, respectively at the freshwater subtidal non-vegetated site to $1675 \mathrm{~g} \mathrm{~m}^{-2}$ and $28 \%$ at the mesohaline site (Table 1).

Sediment $\mathrm{pH}$ within the top $10 \mathrm{~cm}$ tended to increase across sites with increasing salinity and ranged from 5.3 to 6.7 in the Cooper River freshwater sites to about 7.3 in North Inlet and Plum Island (Table 1). Clay content tended to decrease across sites as salinity increased. In the freshwater wetland sites, clay content ranged from 32 to $58 \%$ of dry sediment weight, with an average of $48 \%( \pm 8.9, \pm \mathrm{SD})$, and it decreased to $25 \%$ at the tidal oligohaline marsh, to $15 \%$ at the tidal mesohaline and finally to $4.9 \%$ at the polyhaline site (North Inlet). Although no direct measurements of clay content were made for Plum Island, based on hand sorting of samples and visual observation, we estimated that it was similar to North Inlet.

\section{Sediment phosphatase activity and kinetics}

In surface sediments $(0$ to $10 \mathrm{~cm}$ ), there was a progressive decrease in APA along the salinity gradient from the tidal freshwater to polyhaline sites, and APA was significantly greater in all Cooper River sites than those in polyhaline control sites at North Inlet or Plum Island (Table 2). APA in tidal freshwater marshes was almost an order of magnitude greater than those of control sites at both North Inlet and Plum Island. APA averaged $29.3 \pm 18.8 \mu \mathrm{mol}$ p-nitrophenol released $\mathrm{g}^{-1} \mathrm{~h}^{-1}$ across all Cooper River freshwater sites (i.e. excluding brackish sites), in comparison to $1.5 \pm 0.8 \mu \mathrm{mol}$ p-nitrophenol released $\mathrm{g}^{-1} \mathrm{~h}^{-1}$ in North Inlet control plots and $3.2 \pm 1.5 \mu \mathrm{mol} p$-nitrophenol released $\mathrm{g}^{-1} \mathrm{~h}^{-1}$ in Plum Island controls (Table 2). Among the tidal freshwater sites, APA ranged from 7.9 at the freshwater subtidal non-vegetated site to $63.2 \mu \mathrm{mol} p$-nitrophenol released $\mathrm{g}^{-1} \mathrm{~h}^{-1}$ at freshwater Dense Emergent Site 2. Sediment APA was $12.6 \pm 2.9$ and $21.2 \pm 0.3 \mu \mathrm{mol}$ p-nitrophenol 
Table 2. Arithmetic mean $( \pm 1 \mathrm{SD})$ acid phosphatase activity $(\mathrm{APA})(\mathrm{n}=3)$ measured at an initial substrate concentration of $25 \mathrm{mM}$, and least-squares estimates $( \pm 1 \mathrm{SE})$ of $V_{\max }$ for APA in surface sediments $(0 \mathrm{to} 5 \mathrm{~cm})$ for study habitats from 3 estuaries. The unit for APA is $\mu$ mol $\mathrm{p}$-nitrophenol released $\mathrm{g}^{-1}$ dry sed. $\mathrm{h}^{-1}$. $V_{\max }$ is expressed as $\mu \mathrm{mol} \mathrm{p}$-nitrophenol released $\mathrm{g}^{-1}$ dry sed. $\mathrm{h}^{-1}$. The initial substrate concentrations for measurements of phosphatase kinetics ranged from 0.5 to $25.0 \mathrm{mM}$. SAV: submerged aquatic vegetation

\begin{tabular}{|c|c|c|c|c|c|}
\hline Estuary & Site & $\begin{array}{l}\text { Marsh } \\
\text { type }\end{array}$ & $\begin{array}{c}\text { Acid } \\
\text { phosphatase } \\
\text { activity }\end{array}$ & $\begin{array}{l}\text { APA } \\
V_{\max }\end{array}$ & $\begin{array}{c}\text { Model } \\
\mathrm{R}^{2}\end{array}$ \\
\hline \multirow[t]{8}{*}{$\begin{array}{l}\text { Cooper } \\
\text { River }\end{array}$} & $\begin{array}{c}\text { Subtidal } \\
\text { non-vegetated }\end{array}$ & Open water & $7.9(1.6)$ & $16.2(4.1)$ & 0.93 \\
\hline & SAV & Open water & $18.6(1.2)$ & $25.2(2.3)$ & 0.96 \\
\hline & SAV + emergent & Tidal freshwater & $28.6(6.6)$ & $44.5(6.9)$ & 0.82 \\
\hline & Sparse emergent & Tidal freshwater & $23.8(3.6)$ & $58.3(20.6)$ & 0.95 \\
\hline & Dense Emergent 1 & Tidal freshwater & $33.8(6.8)$ & $30.7(5.0)$ & 0.81 \\
\hline & Dense Emergent 2 & Tidal freshwater & $63.2(5.6)$ & $78.5(6.0)$ & 0.94 \\
\hline & Dense Emergent 3 & Tidal oligohaline & $12.6(2.9)$ & $13.7(1.0)$ & 0.85 \\
\hline & Dense Emergent 4 & Tidal mesohaline & $21.2(0.3)$ & 25.4 (1.9) & 0.95 \\
\hline \multirow{5}{*}{$\begin{array}{l}\text { North } \\
\text { Inlet }\end{array}$} & Control & Tidal polyhaline & $1.5(0.8)$ & $2.1(0.7)$ & 0.48 \\
\hline & P-fertilized & Tidal polyhaline & $1.2(0.1)$ & $2.6(1.1)$ & 0.78 \\
\hline & N-fertilized & Tidal polyhaline & $6.4(3.0)$ & $29.9(19.8)$ & 0.94 \\
\hline & $\mathrm{N}+\mathrm{P}$-fertilized & Tidal polyhaline & $5.9(1.7)$ & $13.8(5.6)$ & 0.86 \\
\hline & $N+P-15 y r$ & Tidal polyhaline & $6.4(1.9)$ & $9.0(1.7)$ & 0.83 \\
\hline Rowley & Control & Tidal polyhaline & $3.2(1.5)$ & $6.2(1.2)$ & 0.43 \\
\hline River & $\mathrm{N}+\mathrm{P}$-fertilized & Tidal polyhaline & $5.4(0.0)$ & $6.2(0.4)$ & 0.96 \\
\hline
\end{tabular}

released $\mathrm{g}^{-1} \mathrm{~h}^{-1}$ for the oligohaline and mesohaline habitats, respectively, which were also significantly higher than those of polyhaline sites.

The trend for phosphatase kinetics of sediments in the depth range of 0 to $5 \mathrm{~cm}$ was the same as that for APA. $V_{\text {max }}$ tended to decrease across sites with increasing salinity (Table 2). In tidal freshwater marshes, $V_{\max }$ ranged from 16.2 (subtidal non-vegetaged site) to 78.5 (Dense Emergent Vegetation 2) $\mu \mathrm{mol}$ p-nitrophenol released $\mathrm{g}^{-1}$ $\mathrm{h}^{-1}$. The tidal oligohaline site had a $V_{\max }$ of $13.7 \pm 1.0( \pm \mathrm{SE})$ and the tidal mesohaline site had a $V_{\max }$ of $25.4 \pm 1.9 \mu \mathrm{mol}$ $\mathrm{p}$-nitrophenol released $\mathrm{g}^{-1} \mathrm{~h}^{-1}$. All were significantly higher than those in salt marsh control plots at North Inlet or Plum Island, which were 2.1 and $6.2 \mu \mathrm{mol}$ p-nitrophenol released $\mathrm{g}^{-1} \mathrm{~h}^{-1}$, respectively (Table 2). There was no trend in $K_{\mathrm{m}}$ values among the sites, which varied from 1.5 to $76.4 \mathrm{mmol}$ (data not shown).

\section{Fertilization experiments}

\section{Plant response}

In North Inlet, the marsh grass Spartina alterniflora did not respond to fertilization with phosphorus only, but peak standing biomass increased significantly after fertilization with nitrogen only and with nitrogen plus phosphorus (Table 1). The height and stem density of Spartina (data not shown) also increased sub- stantially in N-treated and N + P-fertilized plots. The increase in biomass was most pronounced in plots treated with a combination of $\mathrm{N}$ and $\mathrm{P}$ annually since 1984 (the long-term treatment), resulting in a standing biomass 5 times greater than the controls. N-only and $\mathrm{N}$ $+\mathrm{P}$ fertilization in plots treated since 1996 increased the biomass to 750 and $1105 \mathrm{~g} \mathrm{~m}^{-2}$, respectively, from a mean of $350 \mathrm{~g} \mathrm{~m}^{-2}$ in the controls. In the Plum Island estuary, Spartina alterniflora also responded positively to $\mathrm{N}+\mathrm{P}$ treatment. Peak aboveground biomass in the $\mathrm{N}+\mathrm{P}$ treatment plots averaged $1115 \pm 259$ in contrast to $590 \pm 135 \mathrm{~g}$ $\mathrm{m}^{-2}$ in control plots, although they were not statistically different at the $\mathrm{p}=0.05$ level.

Although the long-term treatment with $\mathrm{N}$ and $\mathrm{P}$ had a significant and positive effect on aboveground biomass, there was no major effect on sediment macro-organic matter. Sediment macro-organic matter content within the 0 to $10 \mathrm{~cm}$ depth range generally ranged from $2287 \mathrm{~g} \mathrm{~m}^{-2}$ in the P-only treatment to $2728 \mathrm{~g} \mathrm{~m}^{-2}$ in the long-term $\mathrm{N}+\mathrm{P}$ fertilization treatment. At depths between 0 and $5 \mathrm{~cm}$, there was actually a decrease in macro-organic matter in the longterm N + P treatment (Morris \& Bradley 1999). At Plum Island, fertilization had no significant effect on sediment macro-organic matter content with values similar to those of North Inlet, around $2500 \mathrm{~g} \mathrm{~m}^{-2}$ within the 0 to $10 \mathrm{~cm}$ depth range.

\section{Sediment APA response}

APA at North Inlet in P-fertilized plots, $1.5 \mu_{\mathrm{mol} \mathrm{g}}{ }^{-1}$ $\mathrm{h}^{-1}$, was not significantly different from that in control plots, $1.2 \mu \mathrm{mol} \mathrm{g}^{-1} \mathrm{~h}^{-1}$. However, the $\mathrm{N}$-only, as well as the short-term $\mathrm{N}+\mathrm{P}$ and long-term $\mathrm{N}+\mathrm{P}$ treatments significantly increased APA by a factor of 4 above the levels of controls (Fig. 1, Table 2). The effect of fertilization on the kinetic parameter $V_{\max }$ was similar to that on APA. There was no effect on the $V_{\max }$ of the P-only fertilization treatment, but the effects of $\mathrm{N}, \mathrm{N}+$ $\mathrm{P}$ and long-term $\mathrm{N}+\mathrm{P}$ fertilization treatments were significant. $V_{\max }$ increased from 2.1 in the control plots and from 2.6 in the P-fertilized plots to 9.0, 13.8 and $29.9 \mu \mathrm{mol} \mathrm{g}^{-1} \mathrm{~h}^{-1}$ in the $\mathrm{N}+\mathrm{P}-15 \mathrm{yr}, \mathrm{N}+\mathrm{P}$-fertilized and $\mathrm{N}$-fertilized plots, respectively. A similar trend was obtained from the fertilization experiment at Plum Island where $\mathrm{N}+\mathrm{P}$ fertilization increased the APA 


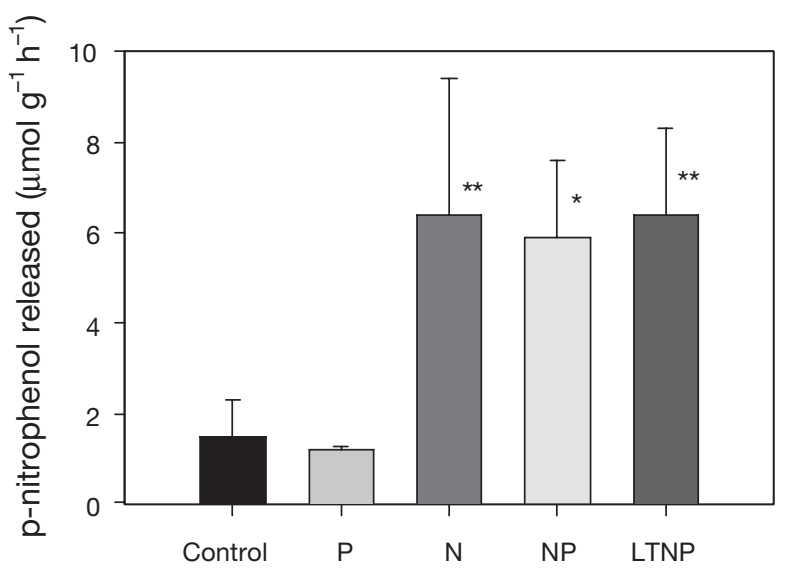

Fig. 1. Mean $(+1 \mathrm{SD}, \mathrm{n}=3$ ) phosphatase activity associated with different fertilization treatments at North Inlet. ${ }^{*} \mathrm{p}<0.10$; ${ }^{*} \mathrm{p}<0.05$. LTNP: $\mathrm{N}+\mathrm{P}$-fertilized for $15 \mathrm{yr}$

from 3.2 in controls to $5.4 \mu \mathrm{mol} \mathrm{g}{ }^{-1} \mathrm{~h}^{-1}$, but this difference was not significant at the $\mathrm{p}=0.05$ level.

Nowhere, not even in the fertilized salt marsh sites, was APA greater than in freshwater, oligohaline or mesohaline sites, except in freshwater subtidal nonvegetated marsh which had almost no vegetation during our study. For example, the APA at the North Inlet $\mathrm{N}$-fertilized site was $6.4 \mu \mathrm{mol} \mathrm{g} \mathrm{g}^{-1} \mathrm{~h}^{-1}$ compared to a rate of $63.2 \mu \mathrm{mol} \mathrm{g}^{-1} \mathrm{~h}^{-1}$ at Cooper River's Dense Emergent Site 2 (Table 2). Peak standing biomass values at these 2 sites were similar. Aboveground standing biomass at the $\mathrm{N}$-fertilized site was $750 \mathrm{~g} \mathrm{~m}^{-2}$, and sediment macro-organic matter was $2568 \mathrm{~g} \mathrm{~m}^{-2}(0$ to $10 \mathrm{~cm}$ depth) compared to an aboveground biomass of $949 \mathrm{~g}$ $\mathrm{m}^{-2}$ and macro-organic matter of $1110 \mathrm{~g} \mathrm{~m}^{-2}$ at Dense Emergent Site 2 (Table 1). However, the N:P molar ratio from surface sediment porewater $(0$ to $10 \mathrm{~cm})$ at the former site, 55.2, was greater than that at the latter site, 11.7 .

\section{Correlates between APA and other site variables}

Our data show that APA was negatively correlated with sediment $\mathrm{pH}\left(\mathrm{p}<0.01, \mathrm{R}^{2}=0.56\right)$ and with porewater salinity ( $p<0.05, R^{2}=0.43$ ) (Fig. 2 , Table 3$)$, but was positively correlated with SOM $\left(\mathrm{p}<0.01, \mathrm{R}^{2}=\right.$ $0.57)$, sediment organic $\mathrm{P}$ (SOP) $\left(\mathrm{p}<0.01 ; \mathrm{R}^{2}=0.50\right)$ and clay content $\left(\mathrm{p}<0.05, \mathrm{R}^{2}=0.37\right.$ ) (Figs. 2,3 \& 4, Table 3). A multiple linear regression model: $\mathrm{APA}=$ $\mathrm{SOM}+$ clay + salinity $+\mathrm{pH}+\mathrm{SOP}$ showed that these 5 factors explained $78 \%$ of the variation of APA ( $p<$ 0.05). APA was not significantly correlated with sulfide, $\mathrm{NH}_{4}{ }^{+}, \mathrm{SRP}$, sediment total $\mathrm{P}$, the N:P ratio, aboveground biomass, or macro-organic matter content (Table 3). A stepwise linear regression set to reject any
Table 3. Correlation of acid phosphatase activity with various edaphic variables and the significance level $(\mathrm{p}) .{ }^{*} \mathrm{p}<0.05$; ${ }^{* *} \mathrm{p}<0.01 .+$ : positive correlation between acid phosphatase activity; -: negative correlation between acid phosphatase activity; SOM: sediment organic matter; SRP: soluble reactive phosphorus; SOP: sediment organic P

\begin{tabular}{|llc|}
\hline Model variables & $\mathrm{R}^{2}$ & $\mathrm{p}$ \\
\hline Standing biomass & 0.01 & \\
SOM & $0.57(+)$ & ${ }^{* *}$ \\
$\mathrm{SOP}$ & $0.50(+)$ & ${ }^{* *}$ \\
$\mathrm{Clay}$ & $0.37(+)$ & ${ }^{*}$ \\
$\mathrm{pH}$ & $0.56(-)$ & ${ }^{* *}$ \\
$\mathrm{SRP}$ & 0.05 & \\
$\mathrm{NH}_{4}{ }^{+}$ & 0.00 & \\
$\mathrm{~N}: \mathrm{P}$ & 0.04 & \\
$\mathrm{~S}^{2-}$ & 0.00 & \\
Salinity & $0.43(-)$ & $*$ \\
SOM + clay + pH & 0.79 & ${ }^{* *}$ \\
SOM + clay + salinity & 0.74 & ${ }^{* *}$ \\
SOM + clay + pH + salinity + SOP & 0.78 & ${ }^{*}$ \\
\hline
\end{tabular}

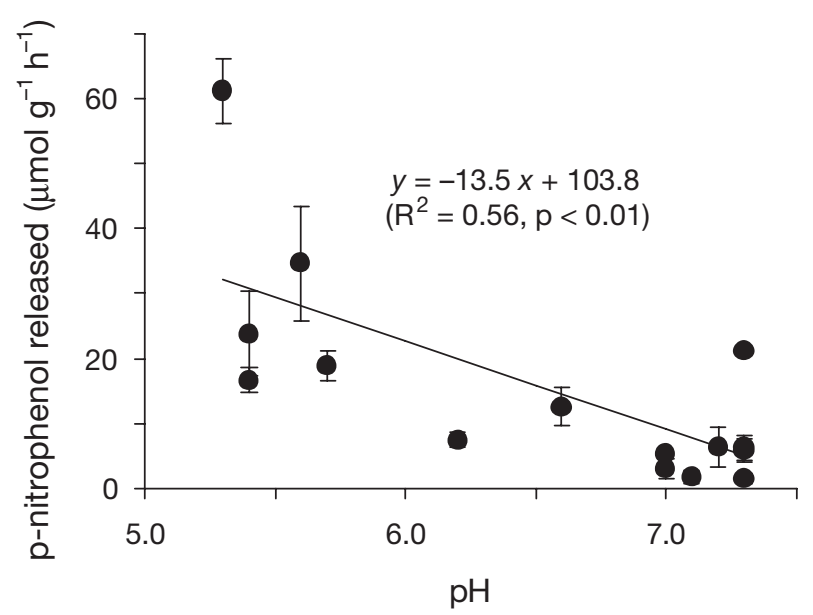

Fig. 2. Significant and negative correlation between acid phosphatase activity and sediment $\mathrm{pH}$ from the depth

variable that failed to produce an $F$ statistic significant at the $\mathrm{p}=0.15$ level identified 3 significant variables in order of $\mathrm{pH}, \mathrm{NH}_{4}{ }^{+}$and standing biomass with partial $\mathrm{r}^{2}$ values of $0.56,0.18$ and 0.08 , respectively, with APA having a negative association with $\mathrm{pH}$ and $\mathrm{NH}_{4}{ }^{+}$, and a positive relationship to biomass.

\section{DISCUSSION}

The APA of marsh sediments along a salinity gradient was influenced by SOM, clay content, salinity, $\mathrm{pH}$ and SOP, which collectively explained $78 \%$ of the APA variation at $\mathrm{p}<0.05$. A stepwise regression identified $\mathrm{pH}$ as the most significant variable. The positive corre- 


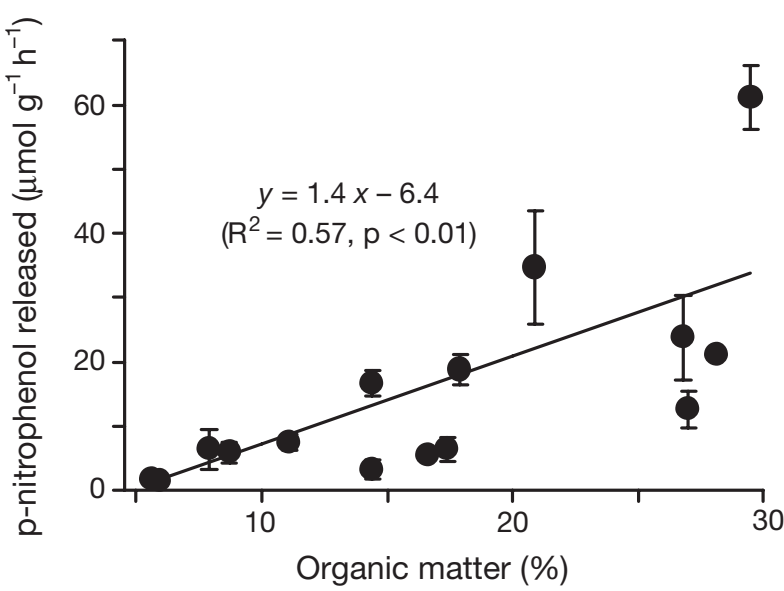

Fig. 3. Significant and positive correlation between acid phosphatase activity and sediment organic matter content from the depth range of 0 to $10 \mathrm{~cm}(\mathrm{n}=15)$

lation between phosphatase activity and SOM content in the 0 to $10 \mathrm{~cm}$ depth range may be due to formation of organic acids and enzyme complexes, which protect the enzyme moiety from reactions with other digesting enzymes and chemical processes. The protection afforded by organic acids allows the enzyme to be sequestered in a suppressed, but chemically active state (McLaren 1975, Wetzel 1991).

Phosphatases are reversibly bound by humic compounds through cation exchange reactions, and under certain circumstances, the immobilized enzyme can be displaced from the complexes and, thus, its functional capacity restored (Ladd \& Butler 1970). Boavida (2000) reported that phosphatase-humic compounds could be separated and reactivated by weak UV light. While SOM sequesters phosphatase, it also provides the substrate for microbial growth and contributes sources of carbon and nitrogen for the synthesis of phosphatase (Spiers \& McGill 1979). In contrast to the study by Harrison (1983), we found that there was a strong positive correlation between phosphatase activity and clay content, which can be explained as follows: free enzymes in solution are subject to degradation and chemical attack, which will reduce the enzymes' functionality (Tabatabai 1982, Wetzel 1991, Boavida 2000); clay particles provide a haven for the enzymes, which can be adsorbed onto the particle surface, thus protecting the phosphatase from degradation by protease or other enzymes. Compared with free enzyme, this complex with clay may reduce the phosphatase activity. Huang et al. (1995) reported that when acid phosphatase was added to a clay slurry with an enzyme concentration less than $5 \mathrm{mg} \mathrm{l}^{-1}$, the enzyme was totally adsorbed onto the clays. The activity of clayadsorbed acid phosphatase ranged from 10 to $40 \%$ of the free enzyme activity, depending on the type of clay, due to an increase in the $K_{\mathrm{m}}$. Consequently, the affinity of acid phosphatase for its substrate is reduced. However, the enzyme's adsorption onto clay is reversible and its activity can be fully recovered in the presence of a high substrate concentration (Stryer 1981, Tabatabai 1982), which suggests that clay has an effect on activity similar to competitive inhibition.

Phosphatase activity tended to decrease with increasing salinity (Table 3). A salt-induced inhibition of phosphatase was observed by Frankenberger \& Bingham (1982), who attributed the effect to osmotic desiccation or specific ion toxicity of soil microbes, or to a salting-out effect on the enzymes themselves. Alternatively, the results of our cross-habitat comparison can be explained by differences in the clay and organic matter content, which decreased as salinity increased. A decrease in clay content would, for example, afford less protection for the enzyme due to complex formation between the clay and phosphatase. Free enzymes are subject to degradation by other enzymes or proteases. Another explanation for the differences in enzyme activity along the salinity gradient is that the plant species in freshwater and salt marshes may have different capacities to synthesize phosphatase enzymes. Differences among plant species with respect to phosphatase activity have been established (Neal 1973).

Differences in APA among fresh and salt marshes may also be related to the availability of orthophosphorus (ortho-P) and SOP. In freshwater sediment, SOP was a dominant form (more than $80 \%$ ). It would be beneficial for the plants/microbes to excrete phosphatase and to utilize ortho-P released from the hydrolysis of SOP. However, SOP was not a dominant form in saltmarsh sediment. If the availability of inor-

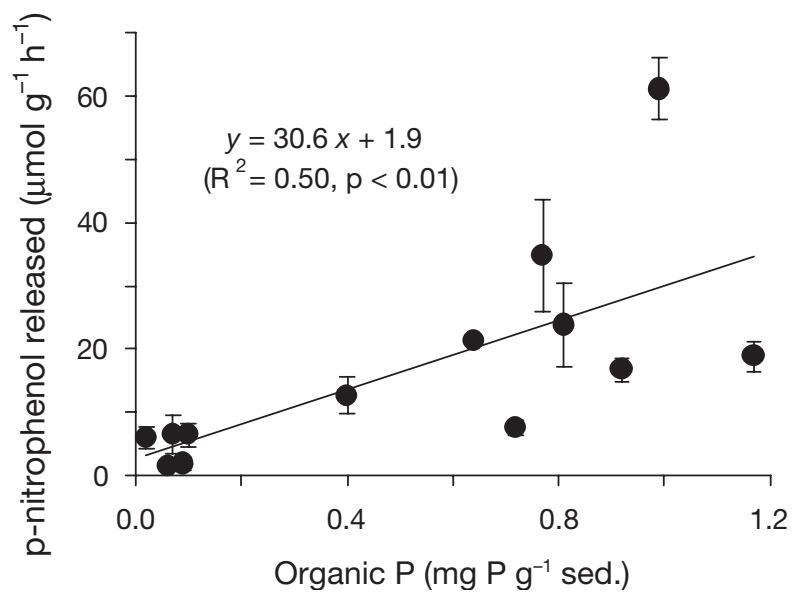

Fig. 4. Significant and positive correlation between acid phosphatase activity and sediment organic phosphorus (SOP) from the depth range of 0 to $10 \mathrm{~cm}(\mathrm{n}=13)$ 
ganic $\mathrm{P}$ is greater in salt marsh environments, then the requirement of organisms for phosphatase synthesis would be reduced. We would expect such a trend if dissolved orthophosphate in salt marshes were primarily derived from inorganic reactions involving iron, sulfur and phosphorus compounds, such as ferric phosphate, calcium phosphate, etc., rather than from remineralization of organic phosphorus compounds. Thus, salt marsh environments may represent an exception to McGill \& Cole's (1981) model in which P availability and P mineralization are tightly coupled.

Based on the responses of vegetation to $\mathrm{N}$ and $\mathrm{P}$ fertilization at North Inlet and Plum Island, it was clearly demonstrated that the salt marsh vegetation was primarily N-limited and secondarily P-limited (Morris 1988, Sundareshwar et al. 2003). APA in control plots and in plots fertilized with only $\mathrm{P}, 1.5(0.8)$ and $1.2(0.1) \mu \mathrm{mol} \mathrm{g}^{-1} \mathrm{~h}^{-1}$, respectively, did not differ. One explanation is that, even including sites fertilized with $\mathrm{P}$, the grand mean of porewater SRP $($ depth $=10 \mathrm{~cm}$ ) was about $15.5 \mu \mathrm{M}$, while laboratory experiments have shown that acid phosphatase was inhibited by phosphate concentrations greater than $0.55 \mathrm{mM}$ (Spiers \& McGill 1979). Porewater SRP concentrations in our fertilized sites averaged only $30 \mu \mathrm{mol} \mathrm{l}^{-1}$ at a depth of $10 \mathrm{~cm}$. However, after fertilizing with nitrogen, APA increased significantly above the levels observed in either controls or P-fertilized sites. This indicates that APA and, thus, P mineralization are related to the $\mathrm{N}$ availability. When organisms are N-limited, the synthesis of phosphatase enzymes should be reduced, and this will tend to conserve phosphorus that, if mineralized, could be lost. As N-loading and productivity increase, the relative demand for phosphorus would increase, which should increase the synthesis of phosphatase.

Ranking the potential environmental controls in order of importance of their influence on AP is difficult because of covariation among the independent variables such as is the case with $\mathrm{pH}$ and salinity. Based on the proportion of total APA variation accounted for by single factors and statistical significance, sediment $\mathrm{pH}$ was an important predictor of APA. Our work raises a question about the relative importance of phosphorus limitation in regulating phosphatase synthesis and other factors that affect the activity of phosphatase. In addition, we have shown that acid phosphatase is the dominant form of phosphatase in Cooper River freshwater tidal marshes (Huang \& Morris 2003), but the differences in APA among habitats shown here raise questions about how the activities of other phosphatase enzymes, such as alkaline phosphatase, vary with $\mathrm{pH}$ and other factors. Additional research is needed before we are able to fully understand the regulation of phosphatase enzymes in natural environments.
Our results differ from those of Sundareshwar et al. (2003) who showed that porewater phosphatase activity at the same site was significantly reduced in the P-only treatment. Moreover, the phosphatase activity in our experiments was far greater than that measured by Sundareshwar et al. (2003), when expressed in common units. This apparent discrepancy can be accounted for by differences in methods. Sundareshwar et al. (2003) measured phosphatase activity in porewater at the in situ $\mathrm{pH}$, while we measured APA in bulk sediment at optimum $\mathrm{pH}$. As discussed above, most APA may be bound to sediment particles, which would increase the activity level of bulk sediment samples. Furthermore, the free phosphatase in porewater may primarily measure the phosphatase activity of unattached bacteria, while measurements in bulk sediment may favor detection of activity associated with attached bacteria and plant roots. Hence, the 2 methods probably measure different phosphatase pools.

Acknowledgements. The authors thank P. V. Sundareshwar and W. Johnson for establishing and maintaining the experimental marsh plots at North Inlet. We thank W. Hankinson for help with analytical and field work. This research was supported by the South Carolina Sea Grant Consortium, and by NSF LTER and LTREB grants. We also thank 4 anonymous reviewers whose comments helped to improve the manuscript.

\section{LITERATURE CITED}

Bieleski RL (1973) Phosphate pools, phosphate transport and phosphate availability. Annu Rev Plant Physiol Plant Mol Biol 24:225-252

Bieleski RL, Johnson PN (1972) The external location of phosphatase activity in phosphorus deficient Spirodela oligorrhiza. Aust J Biol Sci 25:707-720

Boavida MJ (2000) Phosphatase in phosphorus cycling: a new direction for research on an old subject. Arch Hydrobiol Spec Issues Advanc Limnol 55:433-440

Cline JD (1969) Spectrophotometric determination of hydrogen sulfide in natural waters. Limnol Oceanogr 14:454-458

Frankenberger WT, Bingham FT (1982) Influence of salinity on soil enzyme activities. Soil Sci Soc Am J 46:1173-1177

Gee GW, Bauder JW (1982) Particle-size analysis. In: Page AI, Miller RH, Keeney DR (eds) Methods of soil analysis, Part I, 2nd edn. ASA-SSSA (Am Soc Agron and Soil Sci Soc Am), Madison, WI, p 383-411

Harrison AF (1983) Relationship between intensity of phosphatase activity and physicochemical properties in woodland soils. Soil Biol Biochem 15:93-99

Huang Q, Shindo H, Goh TB (1995) Absorption, activities and kinetics of acid phosphatase as influenced by montmorillonite with different interlayer material. Soil Science 159: $271-278$

Huang X, Morris JT (2003) Trends in phosphatase activity along a successional gradient of tidal freshwater marshes on the Cooper River, South Carolina. Estuaries 26(5): 1281-1290

Kjerfve B, Magill KE (1990) Salinity changes in Charleston Harbor 1922-1987. J Waterw Port Coast Ocean Eng 116: 153-168 
Ladd JN, Butler JHA (1970) The effect of inorganic cations on the inhibition and stimulation of protease activity by soil humic acids. Soil Biol Biochem 2:33-40

McGill WB, Cole CV (1981) Comparative aspects of cycling of organic $\mathrm{C}, \mathrm{N}, \mathrm{S}$ and $\mathrm{P}$ through soil organic matter. Geoderma 26:267-286

McLaren AD (1975) Soil as a system of humus and clay immobilized enzymes. Chem Scripta 8:97-99

Morris JT (1988) Pathways and controls of the carbon cycle in salt marshes. In: Hook DD (eds) The ecology and management of wetlands. Timber Press, Portland, OR, p 487-510

Morris JT, Bradley PM (1999) Effects of nutrient loadings on the carbon balance of coastal wetland sediments. Limnol Oceanogr 44:699-702

Neal JLJ (1973) Influence of selected grasses and forbs on soil phosphatase activity. Can J Soil Sci 53:119-121

Olsen SR, Sommers LE (1982) Phosphorus. In: Page AI, Miller RH, Keeney DR (eds) Methods of soil analysis, Part II, 2nd edn. ASA-SSSA (Am Soc Agron and Soil Sci Soc Am), Madison, WI, p 403-430

Otte ML, Morris JT (1994) Dimethylsulphoniopropionate (DMSP) in Spartina alterniflora Loisel. Aquat Bot 48: 239-259

Patni NJ, Phawale SW, Aarsonson S (1977) Extracellular

Editorial responsibility: Victor de Jonge (Contributing Editor), Haren, The Netherlands phosphatases of Chlamydomonas reinhardi and their relation. J Bacteriol 130:205-211

Spiers GA, McGill WB (1979) Effects of phosphorus addition and energy supply on acid phosphatase production and acitivity in soils. Soil Biol Biochem 11:3-8

Strickland JDH, Parsons TR (1972) A practical handbook of seawater analysis, 2nd edn. Fisheries Research Board of Canada, Ottawa

Stryer L (1981) Biochemistry, 2nd edn. WH Freeman, San Francisco, CA

Sundareshwar PV, Morris JT, Koepfler EK, Fornwalt B (2003) Phosphorus limitation of coastal ecosystem process. Science 299:563-565

Tabatabai MA (1982) Soil enzyme. In: Page AI, Miller RH, Keeney DR (eds) Methods of soil analysis, Part II, 2nd edn. ASA-SSSA (Am Soc Agron and Soil Sci Soc Am), Madison, WI, p 903-947

Tadano T, Ozawa K, Sakai H, Osaki M, Matsui H (1993) Secretion of acid phosphatase by the roots of crop plants under phosphorus-deficient conditions and some properties of the enzyme secreted by lupin roots. Plant Soil 155/156:95-98

Wetzel RG (1991) Extracellular enzymatic interactions: storage, redistribution, and interspecific communication. In: Chrost RJ (ed) Microbial enzymes in aquatic environments. Springer-Verlag, New York, p 6-28

Submitted: September 9, 2003; Accepted: November 24, 2004 Proofs received from author(s): April 26, 2005 